\title{
Tingkat Pengetahuan dan Pemahaman Panen Buah pada Tenaga Kerja Permanen Kelapa Sawit di PT Hanusentra Agro Lestari Kalolokan Estate
}

\author{
Nurfadilla \\ Pengelolaan Perkebunan, Politeknik \\ Pertanian Negeri Samarinda, \\ samarinda, 75131, \\ ilailadilla016@gmail.com
}

\author{
Budi Winarni \\ Pengelolaan Perkebunan, Politeknik \\ Pertanian Negeri Samarinda, \\ samarinda, 75131, \\ bwinarni14@gmail.com
}

\author{
Taman Alex* \\ Pengelolaan Pertanian Perkebunan, \\ Politeknik Negeri Samarinda, \\ Samarinda, 75131 \\ tamanalex2@gmail.com \\ *Coressponding Author
}

\begin{abstract}
Abstrak-Penelitian ini dilatar belakangi oleh keberhasilan panen dan produksi yaitu bahan tanam yang digunakan, permanen dengan kapasitas kerjanya, serta alat pendukung lainnya tentang peralatan panen, matang panen, rotasi panen, sistem panen, sarana pasca panen, untuk kelancaran permanenan. Oleh karena itu tujuan dari penelitian ini adalah untuk mengetahui kategori pengetahuan permanen dan produktivitas tenaga kerja permanen kelapa sawit. Pengumpulan data terkait dengan tingkat pengetahuan tenaga kerja permanen diperoleh dari metode observasi, metode wawancara, metode kuesioner dan data sekunder diperoleh dari lembegalembaga/instansi terkait, analisis data penelitian menggunakan metode analisis deskriptif.

Tingkat pengetahuan tenaga kerja di PT Hanusentra Agro Lestasi termasuk kategori baik (B) dengan skor 380 berdasarkan hasil rentang skor yang diberoleh sebesar 80 , produktivitas tenaga kerja permanen rata-rata 143 janjang/HK dengan basis 95 janjang/HK.
\end{abstract}

Kata Kunci- Tingkat Pengetahuan, Produktivitas, Permanen.

\section{Pendahuluan}

Kelapa sawit (Elaeis Guineensis Jacq) merupakan salah satu tanaman perkebunan di Indonesia yang memiliki masa depan cukup cerah. Perkebunan kelapa sawit semula berkembang di daerah Sumatera Utara dan Nanggroe Aceh Darussalam. Namun sekarang telah berkembang ke berbagai daerah seperti, Riau, jambi, Sumatera Barat, Kalimantan Barat, Kalimantan Tengah dan Kalimantan Timur (Sunarko, 2007).

Sebagai negara penghasil minyak sawit terbesar di dunia, Indonesia mempunyai potensi yang besar untuk memasarkan minyak sawit dan inti sawit baik di dalam maupun luar negeri, dalam rangka menunjang peningkatan pembangunan industri minyak sawit di Indonesia (BPS 2018).

Kelapa sawit kini semakin populer karena dapat digunakan sebagai bahan baku alternatif biodiesel. Kelapa sawit merupakan komoditi ekspor Indonesia yang cukup penting sebagai penghasilan divisi negara.
Peningkatan ataupun produksi dan produktivitas suatu perusahaan dipengaruhi oleh peningkatan dan penurunan produksi dan produktivitas tenaga kerja yang tercakup di dalamnya. Karyawan yang berhubungan secara langsung dengan produk yang dihasilkan perkebunan adalah karyawan panen sebagai permanen dari kelapa sawit yang dihasilkan (Fauzi, dkk 2008).

Permanenan merupakan hal yang sangat penting dalam kegiatan produksi tanaman kelapa sawit. Pelaksanaan kegiatan permanenan kelapa sawit berpengaruh langsung terhadap kualitas minyak yang dihasilkan, kegiatan dalam permanenan dimulai dari penentuan kriteria panen, penentuan angka kerapatan panen, taksasi produksi, rotasi panen, penyediaan tenaga kerja yang terampil, teknis panen, pengumpulan hasil dan pengawasan serta pengangkutan panen. Pelaksanaan panen dilakukan sebelum kegiatan panen dilaksanakan.

Selain itu, keberhasilan panen dan produksi tergantung pada bahan tanam yang digunakan, permanen dengan kapasitas kerjanya, peralatan yang digunakan untuk panen, kelancaran transportasi serta alat pendukung lainnya seperti organisasi panen yang baik, keadaan areal, insentif yang disediakan, dan lain-lain (Lubis, 2008).

\section{METODE PENELITIAN}

A. Waktu dan Tempat Penelitian

penelitian dilaksanakan selama satu bulan terhitung dari tanggal 21 September sampai 30 Oktober 2020 dan tempat penelitian dilaksanakan di PT Hanusentra Agro Lestari Kalolokan Estate, Kecamatan Sangkulirang, Kabupaten Kutai Timur, Provinsi Kalimantan Timur.

\section{B. Alat dan Bahan Penelitian}

Alat dan bahan yang digunakan dalam penelitian ini yaitu:

1. Alat
a. Laptop
b. Alat Tulis
c. Kamera/handpone
d. Program Microsoft Office Word
e. Program Microsoft Office Exel

2. Bahan
a. Lembar Observasi
b. Lembar Kuesioner 


\section{c. Dokumentasi}

\section{Metode Pengambilan Data}

Data yang diambil penelitian ini terdiri dari data primer dan data sekunder.

1. Data Primer

a. Observasi

Observasi adalah pengumpulan data yang dilakukan dengan cara meninjau atau mengunjungi perusahaan yang bersangkutan secara langsung, untuk mencatat informasi yang berkaitan dengan masalah yang akan diteliti.

\section{b. Wawancara}

Wawancara dilakukan dengan tanya jawab kepada karyawan. Hal ini dilakukan untuk menggali, mengumpulkan, menemukan informasi yang dibutuhkan atau yang berhubungan dengan penelitian.

c. Kuesioner

Kuesioner merupakan teknik pengumpulan data yang dilakukan dengan cara memberi pertanyaan atau pernyataan tertulis kepada responden untuk dijawabnya.

\section{Data Sekunder}

Pengumpulan dokumentasi dan arsip perusahaan yang berkaitan dengan permanenan dan data lainnya untuk mendukung penelitian yang ada di perusahaan.

\section{Metode Penelitian}

Metode yang digunakan dalam penelitian ini adalah metode survai, karena penelitian ini menggunakan sampel dari satu populasi dan menggunakan kuesioner sebagai alat pengumpulan data pokok.

\section{E. Sampel dan Teknik Sampling}

Untuk menentukan jumlah sampel responden yang akan diambil digunakan pengambilan sampel jenuh atau sensus mengikuti teori Arikunto (2013) yang menyatakan bahwa jika jumlah populasinya kurang dari 100 orang, maka jumlah sampel diambil secara keseluruhan, tetapi jika populasinya lebih besar dari 100 orang, maka bisa diambil $10-15 \%$ atau $20-25 \%$ dari jumlah populasinya.

Berdasarkan teori tersebut maka penulis mengambil seluruh karyawan sampel penelitian tenaga kerja permanen di PT Hanusentra Agro Lestari Kalolokan Estate dari 1 Divisi berjumlah 20 orang.

F. Analisis Data

Dalam membahas hasil penelitian penulis menggunakan metode analisis deskriptif, yaitu suatu cara penulisan yang mengumpulkan, mengklasifikasikan datadata serta selanjutnya menganalisa data sedemikian rupa dihubungkan dengan teori-teori yang berkaitan dengan masalah yang dibahas untuk mengambil kesimpulan.

Pengetahuan di ukuran berdasarkan pertanyaan terhadap indikator pengetahuan permanen tentang persiapan alat panen, pemahaman kriteria matang panen buah kelapa sawit, pemahaman rotasi panen yang tepat, pemahaman sistem panen yang digunakan, dan sarana pasca panen yang digunakan:
1. Pengetahuan permanen tentang persiapan alat, yaitu pengetahuan tenaga kerja permanen tentang alat yang digunakan, seperti gancu, dodos, egrek, pikulan buah/angkong, karung, ember ukuran $8 \mathrm{~kg}$, kapak, dan tali.

Kategori penilaian:

1) Sangat tidak baik (tidak tahu sama sekali alat panen)

2) Tidak baik (tahu 1-2 alat panen)

3) Cukup baik (tahu 3-4 alat panen)

4) Baik (tahu 5-6 alat panen)

5) Sangat baik (tahu $\geq 7$ alat panen)

2. Pemahaman kriteria matang panen buah kelapa sawit, yaitu pemahaman tenaga kerja permanen pada tujuh kriteria matang panen, yaitu fraksi 00 (sangat mentah), fraksi 0 (mentah), fraksi 1 (kurang matang), fraksi 2 (matang I), fraksi 3 (matang II), fraksi 4 (lewat matang I), fraksi 5 (lewat matang II).

Kategori penilaian:

1) Sangat tidak baik (tidak tahu sama sekali kriteria matang panen kelapa sawit)

2) Tidak baik (tahu 1-2 kriteria matang panen kelapa sawit)

3) Cukup baik (tahu 3-4 kriteria matang panen kelapa sawit)

4) Baik (tahu 5-6 kriteria matang panen kelapa sawit)

5) Sangat baik (tahu semua kriteria matang panen kelapa sawit)

3. Pemahaman rotasi panen yang tepat, yaitu pemahaman tenaga kerja permanen pada giliran panen kelapa sawit, seperti 4/7, 5/7, 6/7 dan 7/7.

Kategori penilaian:

1) Sangat tidak baik (tidak mengerti sama sekali sistem rotasi panen kelapa sawit)

2) Tidak baik (mengerti 1 sistem rotasi panen)

3) Cukup baik (mengerti 2 sistem rotasi panen)

4) Baik (mengerti 3 sistem rotasi panen)

5) Sangat baik (mengerti 4 sistem rotasi panen)

4. Pemahaman sistem panen yang digunakan, yaitu pemahaman tenaga kerja permanen pada sistem ancak giring, ancak tetap dan ancak giring tetap.

Kategori penilaian:

1) Sangat tidak baik (tidak mengerti sama sekali sistem panen)

2) Tidak baik (mengerti 1 sistem panen)

3) Cukup baik (mengerti 2 sistem panen)

4) Baik (mengerti 3 sistem panen)

5) Sangat baik (mengerti $>3$ sistem panen)

5. Sarana pasca panen yang digunakan, yaitu pemahaman tenaga kerja permanen pda sarana yang diperlukan setelah melakukan panen, seperti identitas permanen (nomor permanen), transportasi pengangkutan buah, pengawasan muat angkut dan pengawasan mutu buah panen.

Kategori penilaian:

1) Sangat tidak baik (tidak mengerti sama sekali sarana pasca panen)

2) Tidak baik (mengerti 1 sarana pasca panen)

3) Cukup baik (mengerti 2 sarana pasca panen) 
4) Baik (mengerti 3 sarana pasca panen)

5) Sangat baik (mengerti $>3$ sarana pasca panen).

Bobot atau nilai dari masing-masing jawaban yang dipilih oleh responden menurut Skala Likert adalah sebagai berikut :

1. Jawaban yang dipilih adalah sangat tidak baik (STB) mempunyai bobot nilai .

2. Jawaban yang dipilih adalah tidak baik (TB) mempunyai bobot nilai 2 .

3. Jawaban yang dipilih adalah cukup baik (CB) mempunyai bobot nilai 3 .

4. Jawaban yang dipilih adalah baik (B) mempunyai bobot nilai 4 .

5. Jawaban yang dipilih adalah sangat baik (SB) mempunyai bobot nilai 5 .

Pada penelitian ini analisis deskriptif dilakukan dengan membuat kategorisasi (lima kategori) untuk mengetahui tingkat pengetahuan tenaga kerja permanen. Garis kategorisasi dibuat berdasarkan item pernyataan untuk menilai variabel dan juga jumlah sampel yang digunakan. Menurut Sugiyono (2013) rentang skor setiap kategori ditentukan sebagai (1).

$$
\begin{aligned}
\text { Rentang skor kategori } & =\frac{(\mathrm{Rx}[\mathrm{BxST})-[(\mathrm{Rx}[\mathrm{BxSR})}{\mathrm{ST}} \\
& =\frac{(20 \times 5 \times 5)-(20 \times 5 \times 1)}{5} \\
& =80
\end{aligned}
$$

Keterangan : JR : Jumlah responden

JB : Jumlah butir soal

ST : Skor tertinggi

SR : Skor terendah

Setelah diketahui rentang skor kategori setiap variabel, maka garis kategorisasi. Menurut Sugiyono (2013).

Sangat Tidak Baik, Tidak Baik, Cukup Baik, Baik, Sangat Baik dapat dilihat pada tabel 1.

Tabe1. Garis Kategori.

Penilaian kuisioner dilakukan dengan menggunakan scoring artinya masing-masing jawaban responden diberi nilai dengan menggunakan skala likert (Sugiyono, 2013), serta menetapkan data pada tiap nilai. Skor dari hasil tanggapan responden yaitu:

a. Sangat Tidak Baik (STB) = skor terendah + rentang skor kategori

b. Tidak Baik (TB) = skor kategori $\mathrm{TB}+$ rentang

\begin{tabular}{|c|c|c|c|c|} 
STB & TB & CB & B & SB \\
\hline 1 & 2 & 3 & 4 & 5
\end{tabular}

skor kategori.

c. Cukup Baik (CB) = skor kategori $\mathrm{CB}+$ rentang skor kategori .

d. Baik $(\mathrm{B})=$ skor kategori $\mathrm{B}+$ rentang skor kategori.

e. Sangat Baik $(\mathrm{SB})=$ skor kategori $\mathrm{SB}+$ rentang skor kategori.

A. Hasil

\section{HASIL DAN PEMBAHASAN}

1. Karakteristik Responden

Jumlah sampel pada penelitian ini adalah 20 orang

di Divisi 1, responden dalam penelitian ini adalah tenaga kerja permanen PT Hanusentra Agro Lestari Kalolokan
Estate. Terdapat tiga karakteristik responden dilihat dari beberapa sisi,di antaranya: umur, pendidikan, lama kerja.

a. Umur Responden

Umur tenaga kerja permanen PT Hanusentra Agro Lestari Kalolokan Estate dapat dilihat pada tabel 2.

Tabel 2. Umur Responden

\begin{tabular}{|c|c|c|}
\hline Umur (Tahun) & Jumlah Respnden & Persentase \% \\
\hline $21-27$ & 5 & $25 \%$ \\
\hline $28-34$ & 5 & $25 \%$ \\
\hline $35-41$ & 6 & $30 \%$ \\
\hline $42-48$ & 4 & $20 \%$ \\
\hline & 21 & 100 \\
\hline
\end{tabular}

b. Pendidikan Responden

Tingkat Pendidikan tenaga kerja yaitu: Tidak Sekolah, SD, SMP, SMA, berdasarkan hasil observasi yang dilakukan dapat diketahui bahwa tingkat pendidikan karyawan PT Hanusentra Agro Lestrasi Kalolokan Estate paling banyak adalah pada tingkat pendidikan SD dan SMP. Mengenai tingkat pendidikan tenaga kerja dapat dilihat pada tabel 3 .

Tabel 3. Tingkat Pendidikan

\begin{tabular}{|c|c|c|}
\hline $\begin{array}{c}\text { Tingkat } \\
\text { Pendidikan }\end{array}$ & $\begin{array}{c}\text { Jumlah } \\
\text { Responden }\end{array}$ & Persentasi \% \\
\hline Tidak Sekolah & 1 & $5 \%$ \\
\hline SD & 7 & $35 \%$ \\
\hline SMP & 9 & $45 \%$ \\
\hline SMA & 3 & $45 \%$ \\
\hline Total & 20 & $100 \%$ \\
\hline
\end{tabular}

Berdasarkan data pada Tabel 4 dapat diketahui bahwa tingkat pendidikan tenaga kerja permanen yang terbanyak ialah SMP dengan jumlah 9 orang atau (45\%), kemudian tingkat pendidikan SD dengan jumlah 7 orang atau (35\%), tingkat pendidikan SMA dengan jumlah 3 orang atau (15\%) dan Tidak Sekolah dengan jumlah 1 orang atau $(5 \%)$.

c. Lama Bekerja

Berdasarkan lama bekerja di PT Hanusentra Agro Lestari dapat dilihat pada tabel 4.

Tabel 4. Lama Bekerja

\begin{tabular}{|c|c|c|}
\hline $\begin{array}{c}\text { Lama } \\
\text { Bekerja }\end{array}$ & $\begin{array}{c}\text { Jumlah } \\
\text { Responden }\end{array}$ & Persentasi \% \\
\hline $1-3$ & 7 & $35 \%$ \\
\hline $4-6$ & 7 & $35 \%$ \\
\hline $7-9$ & 5 & $25 \%$ \\
\hline $10-12$ & 1 & $5 \%$ \\
\hline Total & 20 & $100 \%$ \\
\hline
\end{tabular}

Dapat diketahui bahwa lama bekerja 1-3 tahun berjumlah 7 orang atau (35\%), kemudian 4-6 tahun berjumlah 7 orang atau (35\%), 7-9 tahun dengan jumlah 5 orang atau (25\%) dan yang paling sedikit ialah 10-12 tahun dengan jumlah 1 orang atau (5\%).

2. Pengetahuan Tenaga Kerja Permanen Kelapa Sawit.

Dalam penelitian ini jawaban responden yang dimaksud adalah tenaga kerja panen di PT Hanusentra Agro Lestari pada Divisi 1 sebanyak 20 
orang, yaitu mengenai tingkat pengetahuan tenaga kerja. Dapat dilihat pada tabel 5.

Tabel 5. Tingkat Pengetahuan Tenaga Kerja Permanenan Kelapa Sawit.

\begin{tabular}{|c|c|c|c|c|c|c|}
\hline \multirow{2}{*}{ Pernyataan } & \multicolumn{5}{|c|}{ Alternatif Jawaban (Nilai } & \multirow{2}{*}{ Jumlah } \\
\cline { 2 - 6 } & 1 & 2 & 3 & 4 & 5 & \\
\hline 1 & 0 & 0 & 0 & 2 & 18 & 20 \\
\hline 2 & 0 & 2 & 12 & 5 & 1 & 20 \\
\hline 3 & 0 & 3 & 11 & 5 & 1 & 20 \\
\hline 4 & 0 & 1 & 6 & 11 & 2 & 20 \\
\hline 5 & 0 & 2 & 4 & 7 & 7 & 20 \\
\hline $\begin{array}{c}\text { Jumlah } \\
\text { (Frekuensi) }\end{array}$ & 0 & 4 & 33 & 30 & 29 & $100 \%$ \\
\hline Persentase & 0 & 8 & 33 & 30 & 29 & $100 \%$ \\
\hline
\end{tabular}

Keterangan:

1 = Sangat Tidak Baik $(\mathrm{STB})$

2 = Tidak Baik $(\mathrm{TB})$

3 = Cukup Baik $(\mathrm{CB})$

$4=$ Baik $($ B)

5 = Sangat Baik $(\mathrm{SB})$

Tabularasa skor dapat dilihat pada tabel 6 .

Tabel 6. Tabulasi Skor Tingkat Pengetahuan Tenaga Kerja Permanen Kelapa Sawit

\begin{tabular}{|l|l|l|l|l|}
\hline Tanggapan & $\begin{array}{l}\text { Nilai } \\
\text { katagor } \\
\text { i }\end{array}$ & $\begin{array}{l}\text { Frekuens } \\
\text { i }\end{array}$ & $\begin{array}{l}\text { Persentase } \\
\%\end{array}$ & $\begin{array}{l}\text { Skor } \\
\text { (Frekuens } \\
\text { i x Nilai } \\
\text { Katagori) }\end{array}$ \\
\hline STB & 1 & 0 & 0 & 0 \\
\hline TB & 2 & 8 & 8 & 16 \\
\hline CB & 3 & 33 & 33 & 99 \\
\hline B & 4 & 30 & 30 & 120 \\
\hline SB & 5 & 29 & 29 & 145 \\
\hline Jumlah & & 100 & $100 \%$ & 380 \\
\hline
\end{tabular}

Hasil perhitungan rentang skor yaitu sebagai berikut:

Skor ideal = Jumlah Frekuensi x Nilai Katagori

Skor tertinggi $=100 \times 5=500$

Skor terendah $=100 \times 1=100$

Rentang skor $=$

$$
=\frac{(500-100)}{5}=80
$$

Berdasarkan rentang skor sebesar 80 maka dapat digambarkan tanggapan responden dapat dilihat pada tabel 7.

Tabel 7. Garis Kategorisasi.

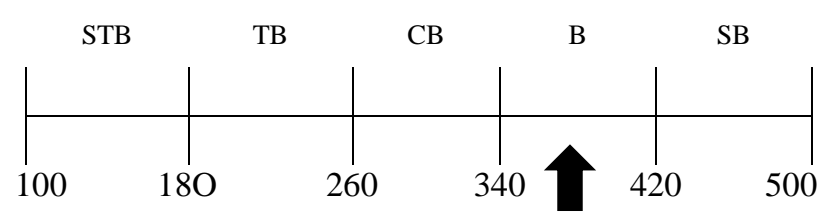

380 (Baik)

Keterangan;

Hasil perhitungan gambar di atas yaitu sebagai berikut:
Sangat tidak baik

$$
\begin{aligned}
& =100-180 \\
& =181-261 \\
& =262-342 \\
& =343-423 \\
& =424-500
\end{aligned}
$$

Sangat Baik $\quad=424-500$

Dari hasil gambar di atas diketahui bahwa dari 20 responden Divisi 1, jumlah skor 380, maka tingkat pengetahuan tenaga kerja permanen termasuk kategori

\begin{tabular}{|c|c|c|}
\hline No & Nama & $\begin{array}{c}\text { Rata-rata Produktivitas } \\
\text { janjang/HK }\end{array}$ \\
\hline 1. & Andi & 142 \\
\hline 2. & Askari & 145 \\
\hline 3. & Herson N.S & 160 \\
\hline 4. & Idhar & 132 \\
\hline 5. & Jumriadi & 148 \\
\hline 6. & Marianus Andi & 121 \\
\hline 7. & M. Jafar & 150 \\
\hline 8. & M. Said & 119 \\
\hline 9. & M. Anis & 114 \\
\hline 10. & M. Sukardi & 142 \\
\hline 11. & Najamuddin & 161 \\
\hline 12. & Oceng & 111 \\
\hline 13. & Rusli & 115 \\
\hline 14. & Rostang & 172 \\
\hline 15. & Stefanus Teu & 144 \\
\hline 16. & Salama & 134 \\
\hline 17. & Salman & 134 \\
\hline 18. & Samsudin & 161 \\
\hline 19. & Tobias Nahak & 161 \\
\hline 20. & Yerison Sopaba & 185 \\
\hline & $\begin{array}{l}\text { Rata-rata } \\
\text { janjang/Hk }\end{array}$ & 143 \\
\hline
\end{tabular}
Baik (B).

3. Produktivitas Tenaga Kerja

Produktivitas tenaga kerja permanen di PT Hanusentra Agro Lestari di Divisi 1 dapat dilihat pada tabel 8.

Tabel 8. Produktivitas Tenaga Kerja

Dapat kita lihat dari Tabel 8, produktivitas tenaga kerja permanen memiliki basis 95 janjang/HK dengan BJR 12,1-14,099 kg, rata-rata produktivitas tenaga kerja yaitu 143 janjang/HK dalam sehari. Tenaga kerja mampu melebihi basis yang telah ditentukan oleh perusahaan, maka akan mendapatkan gaji pokok dan upah premi.

B. Pembahasan

1. Karakteristik responden

a. Umur

Berdasarkan hasil penelitian yang didapatkan untuk tingkat umur responden di PT Hanusentra Agro Lestari berdasarkan

umur yaitu 21-27 tahun sebanyak 5 orang, 28-34 tahun sebanyak 5 orang, kemudian 35-41 tahun 
sebanyak 6 orang dan 42-48 tahun sebanyak 4 orang, dari hasil yang didapatkan dari umur responden bahwa tenaga kerja permanen di lokasi penelitian adalah yang terbanyak pada umur 35-41 tahun, dari umur responden di atas memasuki kategori umur: masa remaja akhir, masa dewasa awal, masa dewasa akhir dan masa lansia (Depkes RI, 2019)

Menurut Depkes RI (2009) kategori umur sebagai berikur:
1) Masa belita
: 0-5 tahun
2) Masa kanak-kanak
: 5-11 tahun
Masa remaja awal
: 12-16 tahun
4) Masa remaja akhir
: 17-25 tahun
: 26-35 tahun
: 36-45 tahun
: 46-55 tahun
: 56-65 tahun
: >65 tahun

jumlah skor 380. Dari keseluruhan nilai kategori tanggapan responden tergolong baik (B).

Menurut pengukuran pengetahuan tenaga kerja permanen kelapa sawit di suatu perusahaan dapat dilihat dari beberapa aspek, yaitu (PPKS, 2009) :

1) Pengetahuan permanen tentang persiapan alat panen dan keterampilan (skill) dalam memanen kelapa sawit.

2) Pemahaman kriteria matang panen buah kelapa sawit.

3) Pemahaman rotasi panen yang tepat.

4) Pemahaman sistem panen yang digunakan.

5) Sarana pasca panen yang digunakan.

a. Pengetahuan permanen tentang persiapan alat panen dari rata-rata jawaban responden tentang pernyataan di atas menunjukkan nilai 3, 92 dengan jawaban responden Sangat Baik (lampiran 5). Hal ini menunjukkan bahwa tingkat pengetahuan dan pemahaman alat panen buah pada tenaga kerja permanenan kelapa sawit nilainya di atas kategori SB. Tenaga kerja menganggap bahwa alat panen yang digunakan ialah alat sehari-hari yang digunakan karena itu tenaga kerja dapat mengetahui tentang persiapan alat panen tersebut.

b. Pengetahuan permanen tentang kriteria matang panen buah kelapa sawit dari ratarata jawaban responden tentang pernyataan di atas menunjukkan nilai 3,25 dengan jawaban responden Tidak Baik (lampiran 5). Hal ini menunjukkan bahwa tingkat pengetahuan dan pemahaman tentang kriteria matang panen kelapa sawit nilainya di atas kategori Tidak Baik. Tenaga kerja menanggapi bahwa tenaga kerja tidak dapat mengetahui tentang kriteria matang panen bahkan tenaga kerja dapat memanen buah mentah yang belum masuk kriteria matang panen.

c. Pengetahuan permanen tentang rotasi panen buah kelapa sawit dari rata-rata jawaban responden tentang pernyataan di atas menunjukkan nilai 3,2 dengan jawaban responden Cukup Baik (lampiran 5). Hal ini menunjukkan bahwa tingkat pengetahuan dan pemahaman tentang rotasi panen buah kelapa sawit nilainya di atas kategori Cukup Baik. Bahwa tenaga kerja cukup tau tentang rotasi yang telah ditetapkan oleh perusahaan.

d. Pengetahuan permanen tentang sistem panen buah kelapa sawit dari rata-rata jawaban responden tentang pernyataan di atas menunjukkan nilai 3,7 dengan jawaban responden Baik (lampiran 5). Hal ini menunjukkan bahwa tingkat pengetahuan dan pemahaman tentang sistem panen buah pada tenaga kerja permanenan kelapa sawit nilainya di atas kategori Baik. Bahwa tenaga 
kerja dapat mengetahui sistem panen yang telah diterapkan oleh perusahaan tersebut.

e. Pengetahuan permanen tentang sara pasca panen buah kelapa sawit dari rata-rata jawaban responden tentang pernyataan di atas menunjukkan nilai 4,9 dengan jawaban responden Sangat Tidak Baik (lampiran 5). Hal ini menunjukkan bahwa tingkat pengetahuan dan pemahaman tentang sarana pasca panen panen buah pada tenaga kerja permanenan kelapa sawit nilainya di atas kategori Sangat Tidak Baik. Bahwa tenaga kerja tidak dapat mengetahui tentang sara pasca panen yang ada di perusahaan.

3. Produktivitas Tenaga Kerja permanen.

Dari hasil Dapat kita lihat dari tabel 8 . Produktivitas tenaga kerja permanen memiliki ratarata 143 janjang/HK dalam sehari. Dan demikian tenaga kerja mampu melebihi basis yang telah ditetapkan oleh perusahaan. Jika tenaga kerja mampu melebihi basis yang ditentukan oleh perusahaan maka akan mendapatkan gaji pokok dan upah premi. Basis yang telah ditetapkan oleh perusahaan yaitu 95 janjang/Hk dengan BJR 12,1-14, $099 \mathrm{~kg}$, untuk tahun tanam 2010.

Hasil penelitian ini sejalan dengan dikatakannya oleh Hidayah (2018), bahwa pada PT MPI setiap karyawan ditargetkan menghasilkan 95 janjang/HK, apabila melebihi target maka karyawan akan mendapatkan premi atau bonus.

\section{KESIMPULAN}

Tingkat pengetahuan tenaga kerja permanen termasuk katagori baik (B) dengan skor 380.

Produktivitas tenaga kerja permanen sebesar 143 janjang/HK dengan basis 95 janjang/HK.

\section{DAFTAR PUSTAKA}

Al Amami N, Rachmat AL. (2014). Analisis FaktorFaktor Yang Mempengaruhi Produktivitas Tenaga Kerja Panen di Perusahaan Perkebunan Kelapa Sawit PT Parasawitarn Kabupaten Aceh Taamiang.

Arikunto, S (2013). Prosedur Penelitian: Suatu Pendekatan Praktik. Jakarta: Rineka Cipta.

BPS. (2018). Statistik Kelapa Sawit. Indonesia.

Hidayah M T M. (2018). Produktivitas Tenaga Kerja Pada Permanen Kelapa Sawit Di PT Multi Pacific Internasional. Skripsi. Jurusan Manajemen Pertanian. Program Studi Pengelolaan Perkebunan Politeknik Pertanian Negeri. Samarinda.

Fauzi, Y., Widyastuti, Y.E., Satyawibawa, I., Hartono, R.. (2008). Kelapa Sawit: Budidaya Pemanfaatan Hasil dan Limbah Analisis Usaha dan Pemasaran Edisi Revisi. Jakarta. Penebar Swadaya.

Idris, Amiruddin. (2016). Pengantar Ekonomi Sumber Daya Manusia. Yogyakarta. Deepublish.
Lubis, A. U. (2008). Kelapa Sawit (Elaeis guineensis jacq) di Indonesia. Medan. Pusat Penelitian Kelapa Sawit.

Manulang, M. (2000). Dasar-Dasar Manajemen. Jakarta. Ghalia Indonesia.

Robbins, S. (2006). Prinsip-prinsip Perilaku Organisasi, Edisi Kelima (Terjemahan Halida dan D Sartika). Jakarta. Erlangga

Sunarko. (2007). Petunjuk Praktis Budi Daya \& Pengolahan Kelapa Sawit. Jakarta . AgroMedia Pustaka.

Sugiyono. (2013). Metode Penelitian Kuantitatif, Bandung Kualitatif dan $R \& D, C V$ Alfa. 